\title{
TESTS OF STEEL CHORD MEMBERS FOR THE BAYONNE BRIDGE
}

\author{
By Ambrose H. Stang, Herbert L. Whittemore, Leroy R. Sweetman
}

ABSTRACT

While designing the Bayonne (Kill van Kull) steel-arch bridge, which crosses from Port Richmond, Staten Island, to Bayonne, N. J., the Bridge Department of the Port of New York Authority requested the cooperation of the National Bureau of Standards in an investigation of the strength and other properties of the lowerchord members. These members were made of carbon-manganese steel and were of the double-box type, having diaphragms and continuous walls.

Because the ratio of the width of the cover plates to their thickness was large, the Port Authority wished to determine whether buckling of the cover plates would cause failure of the members under loads less than their estimated strength.

Two columns were tested. The shortening and the lateral deflection were measured. The tensile properties and the chemical composition of the material were determined from coupons. The test columns were made dimensionally one-half the size of the actual chord members of the bridge.

It was found that-

1. The loading was nearly axial.

2. The Young's modulus of elasticity increased slightly for repeated loadings.

3. For stresses which were nearly the maximum stresses in the columns, the lateral deflection was very small.

4. Under a stress of about $38 \mathrm{kips} / \mathrm{in}^{2}$ the two cover plates began to buckle for their entire length and the buckles increased as the load increased. The ratio of the distance between the nearest lines of rivets to the thickness of the cover plate was 45 .

The results on these two columns are in substantial agreement with the values obtained by the use of Bryan's formula for the compressive stress under which wide plates may be expected to buckle.

After these tests the chord members of the Bayonne Bridge were re-designed so as to prevent failure of these members by buckling of the cover plates.

5. The yield strength of these columns was taken as the stress for which the strain was 0.002 greater than the elastic strain, and the column efficiency obtained by dividing the column yield sirength by the weighted yield strength of the material in the column. The average column yield strength was $57 \mathrm{kips} / \mathrm{in} .^{2}$, and the average column efficiency 97.4 percent.

\section{CONTENTS}

I. The specimens and the method of testing

1. The test columns

(a) Description 628

(b) Testing procedure 630

(1) Compressometers............... 630

(2) Lateral deflection 630

(3) Loading .................... 630 
I. The specimens and the method of testing-Continued.

2. Method of determining the properties of the columns......

(a) Young's modulus _._. 630

(b) Proportional limit_... 631

(c) Column yield strength 631

(d) Weighted yield strength of the material

(e) Column efficiency 631

3. Coupons _._.

(a) General

(b) Shape and size 631

(c) Yield strength

(d) Extensometer 632

(e) Testing machine 632

(f) Speed of the movable platen 632

II. Results for the coupons

1. Tensile tests

2. Chemical composition. 633

III. Results for the columns

1. Shortening 633

2. Lateral deflection 634

3. Maximum load 634

(a) Strength 634

(b) Description of the failure 635

IV. Conclusions_... 637

Note.-The bridge department of the Port of New York Authority designed and built the Kill van Kull Bridge, ${ }^{1}$ between Port Richmond, Staten Island, N. Y., and Bayonne, N. J. The bridge is a two-hinged steel arch, having a span of 1,675 feet. The lower chords of this bridge are carbon-manganese steel. At the time, this was a new type of alloy steel which had heretofore not been used in any large structure, and its behavior in heavy fabricated compression members was unpredictable on the basis of any existing tests. Because of this, and the relative importance of these principal load-carrying members in the bridge, the Port of New York Authority asked the National Bureau of Standards to cooperate in tests to determine their actual strength and behavior under load. In the design, the lower chord members were made constant in depth back to back of chord angles, and the cross-sectional areas were varied to meet the stress requirements by changing the thicknesses of the material. The restriction imposed by proportioning in this manner, and by using the customary limiting minimum thicknesses of material, resulted, for economic reasons, in the use of cover plates having width-to-thickness ratios somewhat larger than conventionally allowed. It was felt that a test of the section designed on this basis would also give valuable data on the buckling strength of these cover plates and the effect of this upon the strength of the member as a whole. The investigation was completed before the final design of the bridge.

\section{THE SPECIMENS AND THE METHOD OF TESTING}

\section{THE TEST COLUMNS}

\section{(a) DESCRIPTION}

The two carbon-manganese test columns, designated CM1 and CM2, were fabricated by riveting. The dimensions are shown in figures 1 and 2, and the nominal dimensions and properties are given in table 1. Column ${ }_{4} \mathrm{CM} 1$, after test, is shown in figure 3.

${ }_{1}$ Pap. Discuss. Am. Soc. Civ. Eng. 56, 487 (1930); Pap. Discuss. Am. Soc. Civ. Eng. 56, 500 (1930). Pap. L. S. Moisseiff, J. Franklin Inst. 213, no. 5, 491 (1932). 


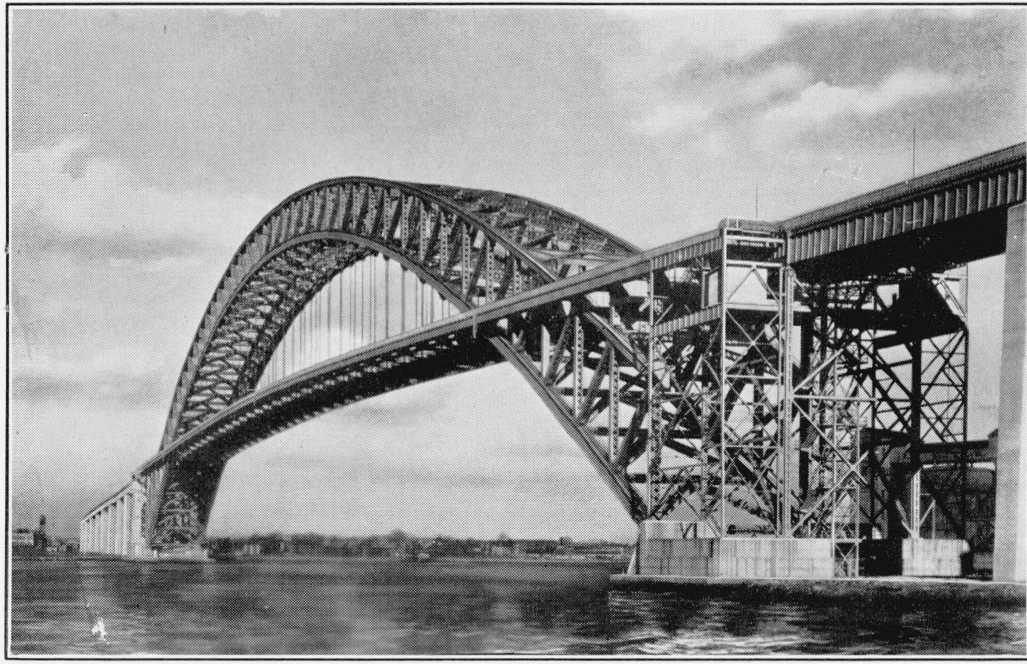

The Bayonne Bridge.

Steel-arch bridge which crosses the Kill van Kull from Port Richmond, Staten Island, N. Y., to Bayonne, N. J. 
TABLE 1.-Nominal dimensions and properties of the test columns

\begin{tabular}{|c|c|c|c|c|c|c|c|c|c|c|c|}
\hline \multirow{2}{*}{$\begin{array}{c}\text { Num- } \\
\text { ber of } \\
\text { columns } \\
\text { tested }\end{array}$} & \multirow{2}{*}{ Symbol } & \multirow{2}{*}{ Kind of steel } & \multirow{2}{*}{$\begin{array}{c}\text { Cross- } \\
\text { sectional } \\
\text { area of } \\
\text { steel }\end{array}$} & \multirow{2}{*}{\multicolumn{2}{|c|}{ Length }} & \multicolumn{2}{|c|}{$\begin{array}{c}\text { Moment of } \\
\text { inertia }\end{array}$} & \multicolumn{2}{|c|}{$\begin{array}{l}\text { Radius of } \\
\text { gyration }\end{array}$} & \multicolumn{2}{|c|}{$\begin{array}{c}\text { Slenderness } \\
\text { ratio }\end{array}$} \\
\hline & & & & & & $I_{x-x}$ & $I_{y-y}$ & $r_{x-x}$ & $r_{y}-y$ & $x-x$ & $y-y$ \\
\hline & $\mathrm{CM} 1, \mathrm{CM} 2 \ldots$ & $\begin{array}{l}\text { Carbon-manga- } \\
\text { nese. }\end{array}$ & $\begin{array}{l}\text { in. }^{2} \\
155.2\end{array}$ & $\begin{array}{l}\mathrm{ft} \\
20\end{array}$ & in. & $\begin{array}{l}\text { in. } \\
31,043\end{array}$ & $\begin{array}{c}\text { in. } 4 \\
17,259\end{array}$ & in. & in. & 17.6 & 23.6 \\
\hline
\end{tabular}

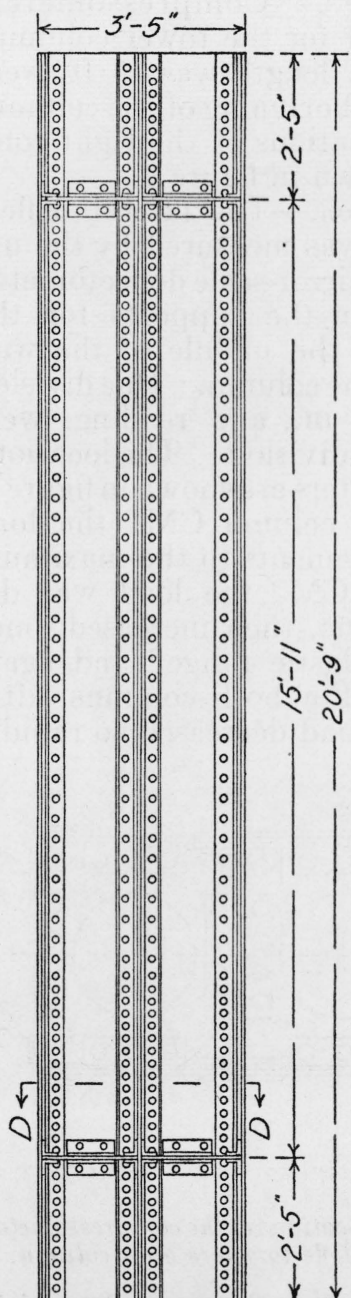

Section $A-A$ $\leftarrow 2^{\prime}-9^{\prime \prime} \longrightarrow$

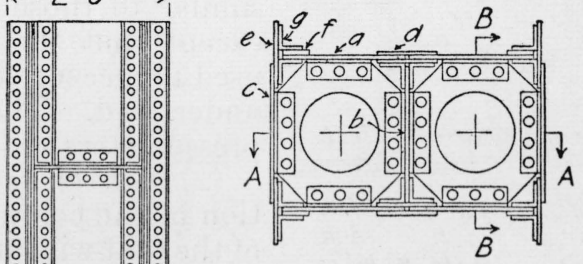

Section D-D

Main Material-20ft 9 in. long Carbon-Manganese Steel a 4 Plates $19 \frac{1}{4}$ in. by $\frac{9}{16}$ in.

b I Plate $20 \frac{1}{4}$ in. by $\frac{1}{2}$ in.

c 2 Plates 21 in. by $\frac{3}{8}$ in.

d 4 Plates 9 in. by $\frac{1}{2}$ in.

e 4 Plates $10 \mathrm{in}$ by $\frac{3}{3}$ in

$f 4$ Plates 4 in. by $\frac{1}{2}$ in.

g 12 Angles 4 in. by 4in. by $\frac{1}{2}$ in?

Diaphragms - Carbon Steel

Rivets $-\frac{3}{4}$ in Carbon Steel

Cutting Diagram

coupon column column coupon

CMI CMI CM2 CM2

$k 2^{\prime}-0^{\prime \prime} * 20^{\prime}-10^{\prime \prime} * 20^{\prime}-10^{\prime *} * 2^{\prime}-0^{\prime \prime} \rightarrow$

$\longleftarrow-45^{\prime}-8^{\prime \prime}+\longrightarrow$

The dimensions of the cover plates of the test columns and of those for the Bayonne Bridge as originally designed are shown in figure 2.

The longitudinal pieces of each column, that is the longitudinal plates and angles, were cut as shown in the cutting diagram in 
figure 1. Each longitudinal piece of the column was match-marked to correspond with a coupon cut from the same plate or angle, and its location in the column was recorded.

\section{(b) TESTING PROCEDURE}

Both columns were tested as flat-end columns by the use of the equipment and methods described in National Bureau of Standards

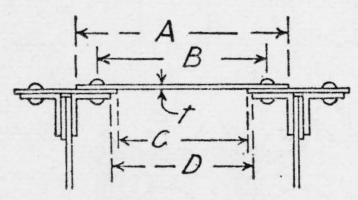

\begin{tabular}{|c|c|c|}
\hline $\begin{array}{l}\text { Cover } \\
\text { Plate }\end{array}$ & $\begin{array}{c}\text { Killvark Kull } \\
\text { Bridge }\end{array}$ & $\begin{array}{l}\text { Test } \\
\text { Column }\end{array}$ \\
\hline & $42 \mathrm{in}$ & 2lin. \\
\hline & $\begin{array}{l}\frac{3}{4} \mathrm{in} \\
3 / \frac{1}{4} \mathrm{in} .\end{array}$ & $\begin{array}{l}\frac{3}{8} \mathrm{in} . \\
16^{\frac{7}{2}} \mathrm{in} .\end{array}$ \\
\hline & $25 \frac{7}{8}$ in. & $13 \mathrm{in}$. \\
\hline & $27 \frac{3}{4} \mathrm{in}$ & $13 \frac{7}{8}$ in. \\
\hline Patio $\frac{B}{{ }^{\prime}}$ & $\begin{array}{l}41.6 \\
345\end{array}$ & $\begin{array}{l}45.0 \\
347\end{array}$ \\
\hline$\| \frac{0}{t}^{\bar{t}}$ & 37.0 & 370 \\
\hline
\end{tabular}

Figure 2.-Dimensions of the cover plates of the test columns and of those for the Kill van Kull Bridge, as originally designed.

Research Paper RP831, Tests of Steel Tower Columns for the George Washington Bridge. ${ }^{2}$

(1) Compressometers.-Compressometers similar to those used for the tower columns, except that the gage length was $15 \mathrm{ft}$, were used to measure the shortening of the columns under load. The locations of the eight compressometers are shown in figure 4.

(2) Lateral deflection.-The lateral deflection of the columns was measured by the use of the taut-wire and mirror-scale deflectometer. The distance between the supports for the wire was $15 \mathrm{ft}$, and the middle of the wire was at midheight of the column. One division on the scale was 0.1 in., and readings were estimated to 0.1 of a division. The locations of the four deflectometers are shown in figure 4.

(3) Loading.-For column CM1 the load was increased by increments to the maximum value. For column CM2 the load was decreased to a low value, then increased, once when the load approached the end of the "elastic range" and again when the column had yielded plastically. For both columns, after the maximum load had been reached, the load decreased so rapidly that the beam of the testing machine could not be balanced. The test was therefore discontinued.

\section{METHOD OF DETERMINING THE PROPERTIES OF THE COLUMNS}

(a) YOUNG'S MODULUS

The average Young's modulus of elasticity for each column was determined from the values of average stress and average compressometerstrain. The average stress was obtained by dividing

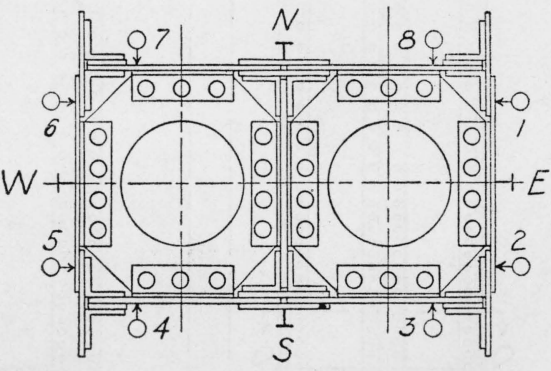

Icompressometer

$T$ Deflectometer

FIGURE 4.-Locations of the compressometers and of the deflectometers on a column. the load by the nominal cross-sectional area of the column. The arithmetical average of the eight compressometer strains for each load was taken as the average compressometer strain. The computed strains obtained by dividing the average stresses in the elastic range by a trial

\footnotetext{
2 J. Research NBS 15, 3 (1935) RP831.
} 


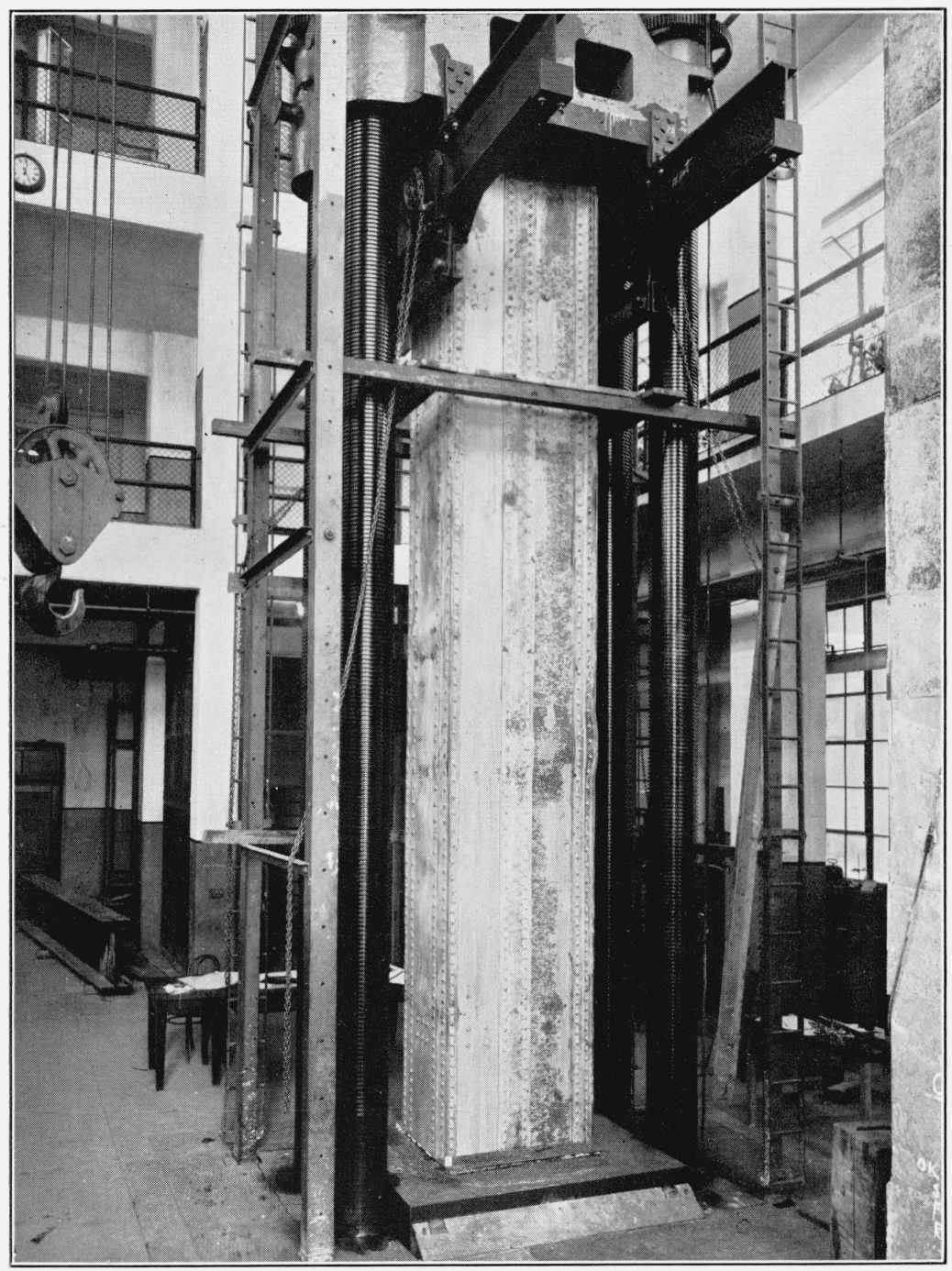

Figure 3.-Column CM1 after test. 
modulus were compared with the average compressometer strains. The trial modulus for which the computed strains agreed most closely with the compressometer strains for loads within the elastic range was taken as the Young's modulus of elasticity of the column.

\section{(b) PROPORTIONAL LIMIT}

A proportional limit for each column was determined as the stress for which the average compressometer strain was 0.000012 greater than the strain computed by using Young's modulus.

(c) COLUMN YIELD STRENGTH

For reasons discussed later, the yield strength of the column was taken as the stress for which the average compressometer strain was 0.002 greater than the strain computed by using Young's modulus. The value for each column was obtained graphically from the stressstrain graph for the column.

\section{(d) WEIGHTED YIELD STRENGTH OF THE MATERIAL}

The weighted average tensile yield strength of the material in the column was obtained from the yield strengths of coupons by weighting them in the ratio of the cross-sectional area of the main member which they represented to the total nominal cross-sectional area of the column.

\section{(e) COLUMN EFFICIENCY}

The column efficiency was obtained by dividing the column yield strength by the weighted yield strength of the material in the column.

\section{COUPONS}

(a) GENERAL

The coupons were machined from the piece marked "coupon" in the cutting diagram in figure 1. This diagram shows the relation of the coupons to the longitudinal pieces used in fabricating each column. For the plates, one coupon was taken at the middle of the plate. For the angles, one coupon was taken at the middle of one of the legs of the angle.

(b) SHAPE AND SIZE

The axis of each coupon was parallel to the rolling direction (axis) of the plate or angle. The coupons were standard ASTM tensile specimens for plates, shapes, and flats. ${ }^{3}$ These coupons had a gage length of 8 in., a width at the reduced section of 1.5 in., and the thickness was that of the material as rolled.

(c) YIELD STRENGTH

The method selected for determining the yield strength of these coupons is essentially the "set method" described by the Section on Elastic Strength of Material of the Technical Committee on Mechanical Testing of the American Society for Testing Materials. ${ }^{4}$ The yield strength was taken as the stress for which the strain was 0.002 greater than the strain computed from the stress and the Young's modulus of elasticity.

${ }_{3}^{3}$ Figure 1, Stand. Am. Soc. Testing Materials [I] 68, (1933).

- Proc. Am. Soc. Testing Materials [I] 31, 602 (1931). 
(d) EXTENSOMETER

The strains in some coupons were measured by the use of a Ewing extensometer having a gage length of $8 \mathrm{in}$. One division on the scale of this instrument corresponded to a strain of 0.000025 in the coupon. The readings were estimated to 0.1 division. For the coupons upon which a Ewing extensometer was not used, the strains were measured by the use of a Berry strain gage having a gage length of $8 \mathrm{in}$. The yield strength was determined graphically by a method which gave values approximating closely those obtained by the use of the Ewing extensometer.

\section{(e) TESTING MACHINE}

The coupons were tested in a screw-power, beam-and-poise machine having a capacity of 100 kips. ${ }^{5}$

\section{(f) SPEED OF THE MOVABLE PLATEN}

For the coupons on which a Ewing extensometer was used, the speed of the movable platen of the testing machine under no load was $0.04 \mathrm{in} . / \mathrm{min}$, and this speed was maintained until the stress was about three-quarters of the yield strength. For higher stresses the speed was $0.01 \mathrm{in} . / \mathrm{min}$. After the extensometer was removed the speed was $0.4 \mathrm{in} . / \mathrm{min}$ until the coupon ruptured.

For the coupons on which a Ewing extensometer was not used, the speed was $0.04 \mathrm{in} . / \mathrm{min}$ until the yield strength was observed. For higher stresses the speed was 0.4 in./min.

\section{RESULTS FOR THE COUPONS}

\section{TENSILE TESTS}

The results of the tensile tests of the coupons are given in table 2 . The properties of the material are average values for the longitudinal members of the same size and shape.

TABLE 2.-Results of the tensile tests of coupons

COLUMN CM1-CARBON-MANGANESE STEEL

\begin{tabular}{|c|c|c|c|c|c|c|}
\hline \multicolumn{2}{|c|}{ Column material } & \multirow{2}{*}{$\mid \begin{array}{c}\text { Num- } \\
\text { ber of } \\
\text { coupons } \\
\text { tested }\end{array}$} & \multirow{2}{*}{$\begin{array}{c}\text { Yield } \\
\text { strength } \\
\text { (average) }\end{array}$} & \multirow{2}{*}{$\begin{array}{c}\text { Tensile } \\
\text { strength } \\
\text { (average) }\end{array}$} & \multirow{2}{*}{$\begin{array}{l}\text { Elongation } \\
\text { in } 8 \text { in. } \\
\text { (average) }\end{array}$} & \multirow{2}{*}{$\begin{array}{l}\text { Reduction } \\
\text { of area } \\
\text { (average) }\end{array}$} \\
\hline Shape & Nominal size & & & & & \\
\hline $\begin{array}{l}4 \text { plates. } \\
1 \text { plate } \\
2 \text { plates. } \\
4 \text { plates. } \\
4 \text { plates } \\
4 \text { plates } \\
12 \text { angles. }\end{array}$ & $\begin{array}{l}\text { in. } \\
191 / 4 \text { by } 9 / 16 \\
201 / 4 \text { by } 1 / 2 \ldots \\
21 \text { by } 3 / 8 \\
9 \text { by } 1 / 2 \\
10 \text { by } 3 / 8 \\
4 \text { by } 1 / 2 \\
4 \text { by } 4 \text { by } 1 / 2\end{array}$ & $\begin{array}{r}4 \\
1 \\
2 \\
4 \\
4 \\
4 \\
12 \\
\end{array}$ & $\begin{array}{r}\text { kips/in. } \\
59.8 \\
61.9 \\
63.2 \\
54.8 \\
56.3 \\
56.4 \\
56.6 \\
\end{array}$ & $\begin{array}{r}\text { kips/in. }{ }^{2} \\
101.0 \\
104.2 \\
105.2 \\
94.5 \\
91.6 \\
92.5 \\
93.7\end{array}$ & $\begin{array}{r}\text { Percent } \\
17.8 \\
16.4 \\
17.2 \\
19.6 \\
21.6 \\
20.0 \\
20.3\end{array}$ & $\begin{array}{r}\text { Percent } \\
48.1 \\
40.1 \\
45.9 \\
48.7 \\
54.8 \\
47.0 \\
49.8\end{array}$ \\
\hline \multicolumn{2}{|c|}{ Weighted average } & & 58.3 & 97.4 & 19.1 & 48.5 \\
\hline
\end{tabular}

COLUMN CM2-CARBON-MANGANESE STEEL

\begin{tabular}{|c|c|c|c|c|c|c|}
\hline $\begin{array}{l}4 \text { plates } \\
1 \text { plate } \\
2 \text { plates. } \\
4 \text { plates. } \\
4 \text { plates. } \\
4 \text { plates. } \\
12 \text { angles. }\end{array}$ & $\begin{array}{l}191 / 4 \text { by } 9 / 16 \ldots \\
201 / 4 \text { by } 1 / 2 \ldots \\
21 \text { by } 3 / 8 \ldots \\
9 \text { by } 1 / 2 \\
10 \text { by } 3 / 8 \ldots \\
4 \text { by } 1 / 2\end{array}$ & $\begin{array}{r}4 \\
1 \\
2 \\
4 \\
4 \\
4 \\
12\end{array}$ & $\begin{array}{l}60.0 \\
60.0 \\
63.0 \\
55.4 \\
56.2 \\
55.6 \\
56.4\end{array}$ & $\begin{array}{r}98.2 \\
101.4 \\
105.1 \\
96.2 \\
94.6 \\
91.8 \\
93.4\end{array}$ & $\begin{array}{l}18.8 \\
20.2 \\
16.4 \\
18.5 \\
20.4 \\
20.7 \\
19.8\end{array}$ & $\begin{array}{l}46.5 \\
41.0 \\
40.8 \\
46.6 \\
51.0 \\
55.7 \\
50.8\end{array}$ \\
\hline Weighted average & & 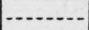 & 58.1 & 96.8 & 19. 2 & 47.7 \\
\hline
\end{tabular}

b. kip = 1,000 ib. 
A typical Ewing stress-strain graph for the carbon-manganese steel is shown in figure 9 of Research Paper 831.

The speed of the movable head of the testing machine was much lower than is customarily used when determining the yield strength. For these coupons the rate at which the stress was increased is more nearly the rate for the columns than the rate customarily used for coupons.

\section{CHEMICAL COMPOSITION}

The Bureau's Chemistry Division made chemical analyses of samples from coupons having the highest and the lowest tensile strength for each thickness and each shape. The results are given in table 3.

TABLE 3.-Chemical composition of the carbon-manganese steel

\begin{tabular}{|c|c|c|c|c|c|c|c|}
\hline \multicolumn{3}{|c|}{ Description of samples } & \multicolumn{5}{|c|}{ Chemical composition } \\
\hline Thickness & Shape & $\begin{array}{l}\text { Tensile } \\
\text { strength }\end{array}$ & Carbon & $\begin{array}{c}\text { Manga- } \\
\text { nese }\end{array}$ & $\begin{array}{l}\text { Phos- } \\
\text { phorus }\end{array}$ & Sulphur & Silicon \\
\hline $\begin{array}{l}\text { in. } \\
1 / 2 \ldots \\
1 / 2 \\
3 / 8 \\
\end{array}$ & $\begin{array}{l}\text { Angle. } \\
\text { Plate_do_. } \\
\end{array}$ & $\begin{array}{r}\text { kips/in. }{ }^{2} \\
88.9 \\
99.1 \\
90.8 \\
105.3\end{array}$ & $\begin{array}{r}\text { Percent } \\
0.31 \\
.33 \\
.31 \\
.36\end{array}$ & $\begin{array}{r}\text { Percent } \\
1.54 \\
1.59 \\
1.54 \\
1.71\end{array}$ & $\begin{array}{r}\text { Percent } \\
0.025 \\
.031 \\
.025 \\
.027\end{array}$ & $\begin{array}{r}\text { Percent } \\
0.020 \\
.021 \\
.018 \\
.026\end{array}$ & $\begin{array}{r}\text { Percent } \\
0.17 \\
.17 \\
.17 \\
.19\end{array}$ \\
\hline $\begin{array}{l}1 / 2 \\
1 / 2 \\
916 \\
916\end{array}$ & \begin{tabular}{|c|}
$\ldots$ do \\
\\
\end{tabular} & $\begin{array}{r}90.5 \\
104.2 \\
88.2 \\
111.0\end{array}$ & $\begin{array}{l}.31 \\
.35 \\
.30 \\
.37\end{array}$ & $\begin{array}{l}\text { 1. } 53 \\
\text { 1. } 72 \\
1.53 \\
1.86\end{array}$ & $\begin{array}{l}.027 \\
.024 \\
.036 \\
.019\end{array}$ & $\begin{array}{l}.014 \\
.018 \\
.018 \\
.018\end{array}$ & $\begin{array}{l}.17 \\
.18 \\
.15 \\
.20\end{array}$ \\
\hline
\end{tabular}

\section{RESULTS FOR THE COLUMNS}

\section{SHORTENING}

For loads which did not exceed the proportional limit the strain was almost the same for each of the compressometers. The average of the values for the eight compressometers was used for the stress-strain graphs shown in figure 5. The elastic properties of the columns are given in table 4. For column CM2, on which the load was released, the Young's modulus of elasticity was slightly greater for the second and the third loading than for the first loading. For this column the proportional limit for the second and the third loadings equaled or

TABLE 4.-Elastic properties of the test columns

\begin{tabular}{|c|c|c|c|c|c|c|c|c|c|c|c|}
\hline \multirow{2}{*}{ Column } & \multicolumn{3}{|c|}{ Maximum stress } & \multicolumn{3}{|c|}{$\begin{array}{l}\text { Young's modulus of } \\
\text { elasticity }\end{array}$} & \multicolumn{3}{|c|}{ Proportional limit } & \multicolumn{2}{|c|}{ Set after- } \\
\hline & $\begin{array}{c}\text { First } \\
\text { loading }\end{array}$ & $\begin{array}{l}\text { Second } \\
\text { loading }\end{array}$ & $\begin{array}{c}\text { Third } \\
\text { loading }\end{array}$ & $\begin{array}{c}\text { First } \\
\text { loading }\end{array}$ & $\begin{array}{l}\text { Second } \\
\text { loading }\end{array}$ & $\begin{array}{c}\text { Third } \\
\text { loading }\end{array}$ & $\begin{array}{c}\text { First } \\
\text { loading }\end{array}$ & $\begin{array}{l}\text { Second } \\
\text { loading }\end{array}$ & $\begin{array}{l}\text { Third } \\
\text { loading }\end{array}$ & $\begin{array}{c}\text { First } \\
\text { loading }\end{array}$ & $\begin{array}{l}\text { Second } \\
\text { loading }\end{array}$ \\
\hline & $\underset{\mathrm{b} 59.0}{\operatorname{kips} / \mathrm{in}^{2}}$ & kips/in. ${ }^{2}$ & kips/in. ${ }^{2}$ & kips/in.2 ${ }^{2}$ & ${ }^{2}$ kips/in. ${ }^{2}$ & kips/in. ${ }^{2}$ & kips/in. ${ }^{2}$ & kips/in. ${ }^{2}$ & kips/in. ${ }^{2}$ & & \\
\hline CM2... & $\begin{array}{r}59.0 \\
28.0\end{array}$ & 40.0 & 58.6 & $\begin{array}{l}25,100 \\
28,200\end{array}$ & 28,350 & 28,450 & $\begin{array}{l}28.0 \\
26.0\end{array}$ & 32.0 & 40.0 & 0.000030 & 0.000130 \\
\hline
\end{tabular}

a Determined as the stress for which the average compressometer strain was 0.000012 greater than the $s$ train computed by the use of Young's modulus of elasticity.

- Final maximum stress, preceding failure.

exceeded the stress applied in the previous loading. Although the stress for the first loading exceeded the initial proportional limit by $2 \mathrm{kips} / \mathrm{in}^{2}$, the permanent set was small after this load was released. 
After the second loading, the permanent set of column CM2 was slightly less than that for tower column TM2 (carbon-manganese steel) after the second loading. (See table 5, Research Paper 831.) The maximum stress for the second loading was 40 kips/in. ${ }^{2}$ for both of these columns.

\section{LATERAL DEFLECTION}

The deflections for each side of the column are shown in figure 6 . For both columns the lateral deflections were small until the final maximum load was approached.

\section{MAXIMUM LOAD}

\section{(a) STRENGTH}

The column strengths given in Technologic Paper 328 were the values of the first maximum stress. It was stated that "the prac-

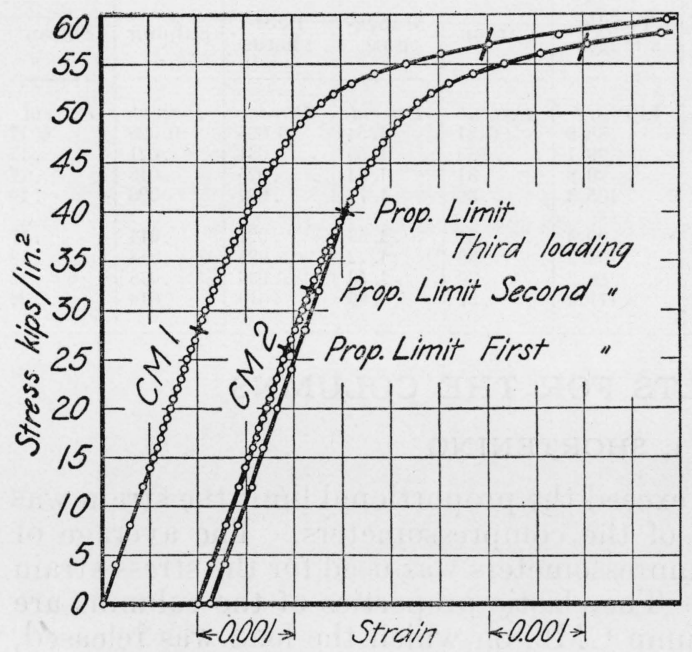

FIGURE 5.-Stress-strain graphs for the columns. tically definite first maximum stress, occurring: before any appreciable lateral deflection of the column, and fairly reproducible when the column material and test conditions are reproduced, should furnish a good measure of the strength of the column in practical use. This justifies the practice followed in this report of recording the first maximum stress observed in a column test as the 'column strength' under the given test conditions. However, as was previously pointed out, this would not be justified in case no maximum were observed before the column was badly deformed."

With regard to the procedure that should be followed when no maximum is observed before the column is badly deformed, it was stated that "the best criterion could only be determined by a series of tests on columns in this range, in which the stress deformation curves were carefully determined."

In tensile tests of steels which do not show a definite yield point, it has become customary to define a yield strength in terms of the stress necessary to produce a definite strain (usually 0.002) in the coupon in excess of the computed elastic strain. It seemed probable that a similar definition of a column yield strength would be satisfactory for columns for which no definite first maximum load is observed, and for this reason the column yield strengths in Research Paper 831 were computed on this basis.

The Bayonne test columns did show a definite first maximum stress, after which the stress decreased rapidly. This first maximum 
stress could therefore have been used when computing the column efficiency as in Technologic Paper 328. However, the method adopted in Research Paper 831 was followed, the column efficiency being determined by dividing the column yield strength by the weighted yield strength of the material in the column.

The strengths of the test columns are given in table 5. The average column efficiency was 97.4 percent. This value is slightly less than the column efficiency of tower columns TM1 and TM2 of carbonmanganese steel, which had a greater slenderness ratio (tower columns 28.9, chord columns 17.6).

The final maximum stress was on the average 3.3 percent greater than the column yield strength.

\section{(b) DESCRIPTION OF THE FAILURE}

The failures of the chord columns have been described by $R$. S. Johnston. ${ }^{6}$

Neither of these columns showed either "pick-up" or "hang-on", ? probably because the longitudinal pieces in the column were relatively thin.

TABLE 5.-Strength and efficiency of the test columns

\begin{tabular}{|c|c|c|c|c|c|}
\hline Column & $\begin{array}{c}\text { First } \\
\text { and final } \\
\text { maximum } \\
\text { load }\end{array}$ & $\begin{array}{l}\text { Weighted } \\
\text { yield } \\
\text { strength } \\
\text { of material }\end{array}$ & $\begin{array}{l}\text { Column } \\
\text { yield } \\
\text { strength } a\end{array}$ & $\begin{array}{l}\text { First and } \\
\text { final } \\
\text { maximum } \\
\text { stress }\end{array}$ & $\begin{array}{c}\text { Column } \\
\text { efficiency } \\
\text { (based on } \\
\text { column yield } \\
\text { strength) }\end{array}$ \\
\hline $\begin{array}{l}\text { CM1 } \\
\text { CM2 }\end{array}$ & $\begin{array}{l}\text { kips } \\
9,156 \\
9,102\end{array}$ & $\begin{array}{r}\text { kips/in. }{ }^{2} \\
58.7 \\
58.1\end{array}$ & $\begin{array}{r}\text { kips/in. }{ }^{2} \\
57.0 \\
56.8\end{array}$ & $\begin{array}{r}\text { kips/in. } .^{2} \\
59.0 \\
58.6\end{array}$ & $\begin{array}{r}\text { Percent } \\
97.1 \\
97.8\end{array}$ \\
\hline A verage & 9,129 & 58.4 & 56.9 & 58.8 & 97.4 \\
\hline
\end{tabular}

a Stress for which the strain was 0.002 greater than the elastic strain.

Column CM2 was tested before column CM1. At the greater loads column CM2 scaled on all four sides. Under a stress of 53 kips/in. ${ }^{2}$ the two cover plates, $c$ in figure 1 , were definitely buckled over their entire length. Under the maximum load, buckles appeared suddenly in the adjacent sides just above midheight as shown in figures 7 and 8 .

The ratio of the distance between the nearest lines of rivets to the thickness of

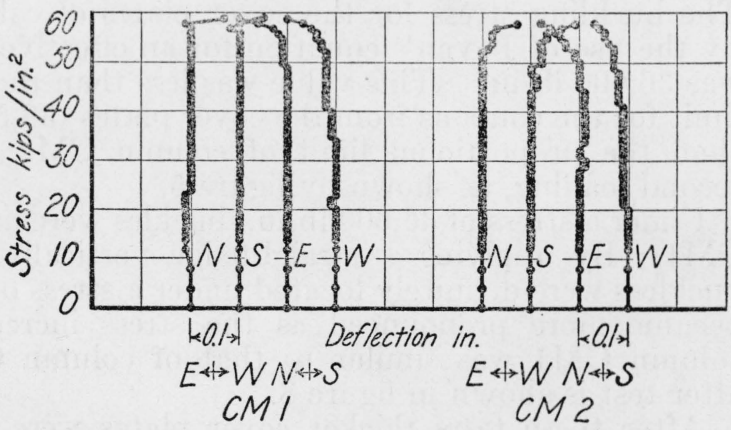

Figure 6.-Lateral deflections for the columns.

the cover plate was 45 , as given in figure 2 . This ratio is limited to a maximum of 40 in some specifications for carbon steel. ${ }^{8}$ For alloy steels a ratio not exceeding 36 is allowed. Although the ratio for the

6 Eng. News-Rec. 103, 999 (1929)

7 Teeh. Pap. BS 21, (1926) T328 (particularly p. 57-60).

8 Bul. Am. Railway Eng. Assn., no. 374 (1935) Report Com. Iron and Steel Structures. $66929-36-8$ 
cover plates of the chord columns somewhat exceeded this specification value, it was expected that the cover plate would be restrained sufficiently by the angles to prevent failure of the column by buckling of the cover plates.

The buckling of wide plates in ships under compressive loads was discussed mathematically by Bryan. ${ }^{9}$ His results lead to the following equation for the stress at which plates simply supported at the lateral edges buckle elastically:

in which

$$
S=3.5 \frac{E t^{2}}{b^{2}}
$$

$S=$ stress at which plate buckles, $\mathrm{lb} / \mathrm{in}^{2}{ }^{2}$

$E=$ Young's modulus of elasticity, $\mathrm{lb} /$ in. $^{2}$

$t=$ thickness of plate, in.

$b=$ width of plate, in.

The constant 3.5 depends upon the assumption that the Poisson's ratio for the plate is 0.25 . It is also assumed that the plate is infinitely long and that the proportional limit of the plate is greater than the buckling stress.

The average value of the Young's modulus of elasticity for the coupons from the cover plates of the chord columns was 29,100,000 $\mathrm{lb} / \mathrm{in} .{ }^{2}$ for column CM1 and 28,800,000 lb/in. ${ }^{2}$ for column CM2. Bryan shows that the distance from crest to crest of the buckles measured longitudinally along the plate, is equal to the effective width of the plate. The distance from crest to crest on column CM2, after the test, was 19.7 inches. This is greater than the distance between rivet lines (16.88 in.), but less than the width of the cover plate (21 in.). Apparently the cover plates were restrained by the angles so that the effective width was less than the actual width but greater than the distance between the nearest rivet lines. The ratio of this effective width to the thickness of the cover plate was 52.4. The buckling stress for the cover plates of column CM2, computed by the use of Bryan's equation for an effective width of 19.7 inches, was $36,600 \mathrm{lb} / \mathrm{in}^{2}{ }^{2}$ This value was less than the average proportional limit for the coupons from the cover plates $\left(39,500 \mathrm{lb} / \mathrm{in} .^{2}\right)$ but greater than the proportional limit of column CM2 for the first and the second loading, as shown by figure 5 .

Under a stress of $36,600 \mathrm{lb} /$ in. $^{2}$ buckles were not apparent in column CM1. By applying a straightedge vertically to the cover plates, buckless were definitely located under a stress of $38,000 \mathrm{lb} / \mathrm{in}^{2}{ }^{2}$ They became more pronounced as the stress increased. The failure of column CM1 was similar to that of column CM2. Column CM1 after test is shown in figure 8 .

After these tests thicker cover plates were used in the Bayonne Bridge to increase resistance to buckling.

Although the results on these two chord columns do not prove that Bryan's formula is correct, they are in substantial agreement with the values obtained by the use of the formula for these columns. For fabricated columns similar to these chord columns, a value of 36 for the ratio of width of plate to thickness may safely be used in design. 


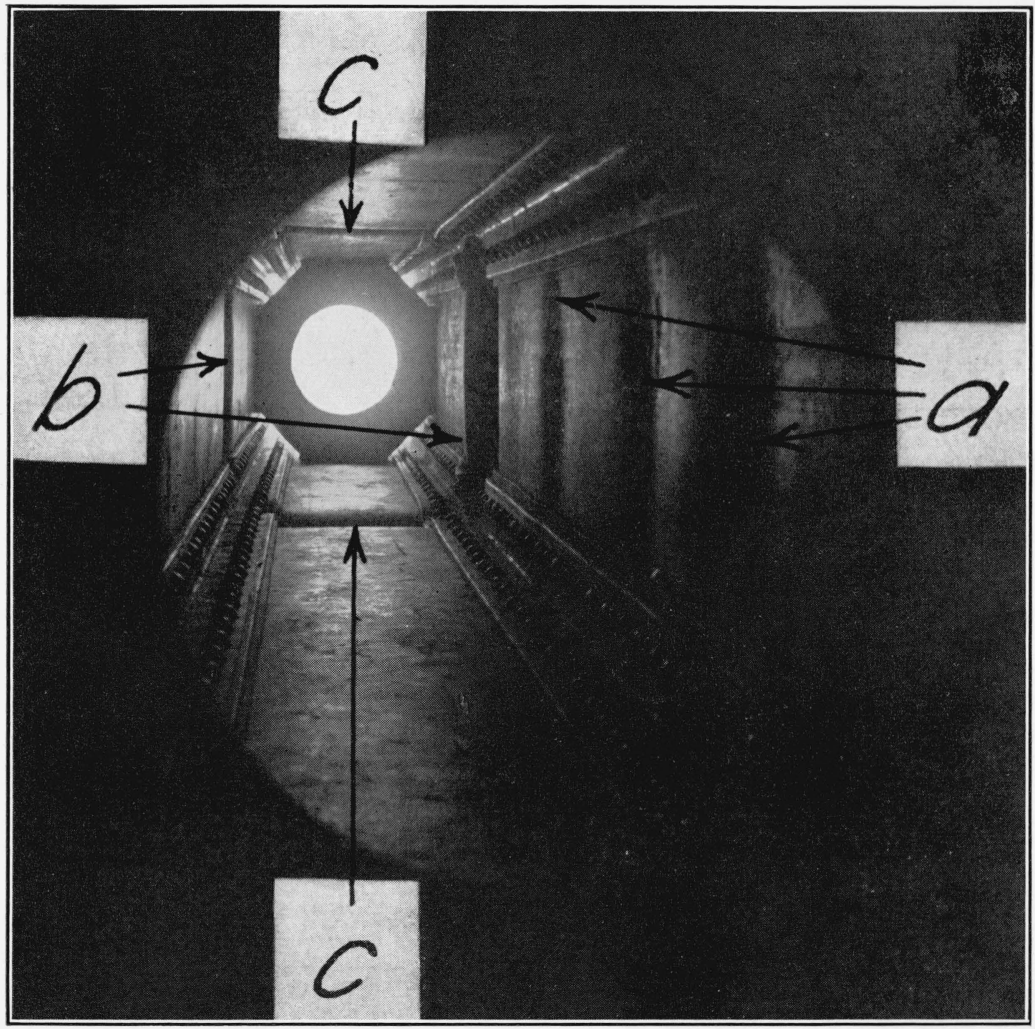

FIGURE 7.-Buckles in column CM2, after test, as they appeared from the bottom of the column.

The buckles a-a were definite at a stress of $53 \mathrm{kips} / \mathrm{in} .^{2}$ Under the maximum load the buckles b-b increased greatly and buckles $\mathrm{c}-\mathrm{c}$ appeared suddenly. 


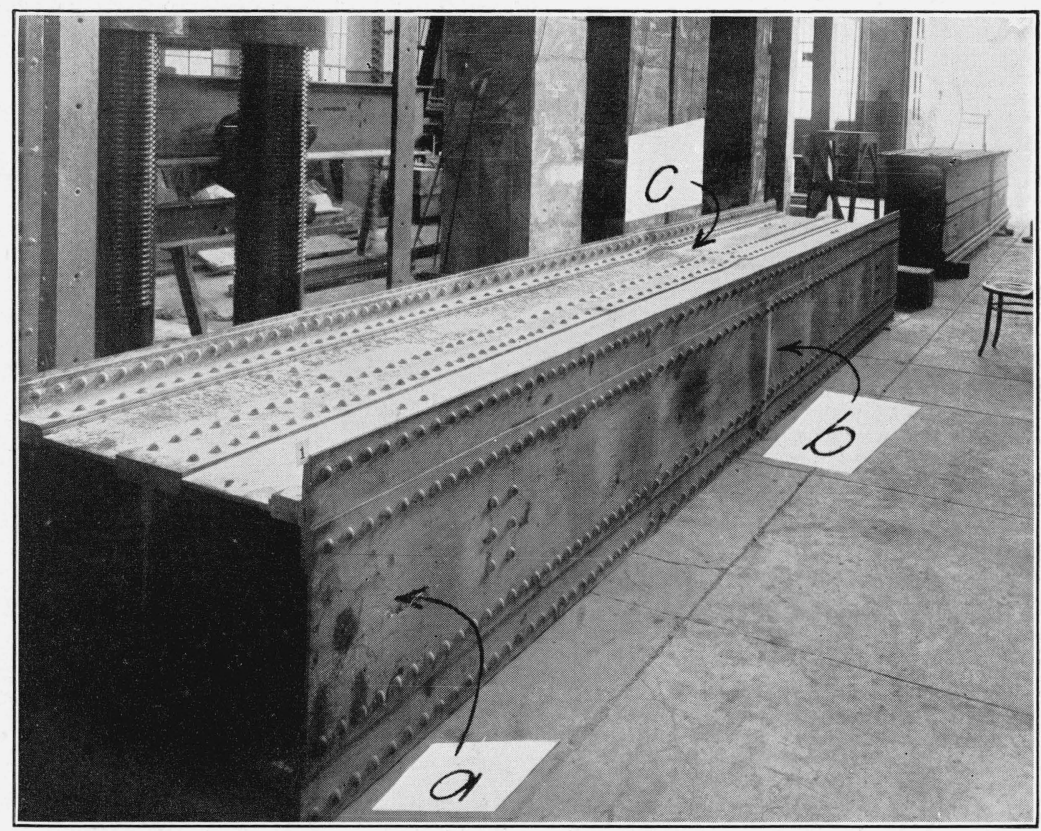

FIGURE 8.-Chord column CM1 after test.

There were buckles for the entire length of the cover plate a. Under the maximum load the buckle b increased greatly and buckle c appeared suddenly. 


\section{CONCLUSIONS}

1. The loading was nearly axial.

2. For stresses which were nearly the maximum stresses in the columns the lateral deflection was small.

3 . Under a stress of about $38 \mathrm{kips} / \mathrm{in}^{2}$ the two cover plates began to buckle for their entire length, and the buckles increased as the load increased.

4. The yield strength of these columns was taken as the stress for which the strain was 0.002 greater than the elastic strain and the column efficiency obtained by dividing the column yield strength by the weighted yield strength of the material in the column. The average column yield strength was $57 \mathrm{kips} / \mathrm{in} .{ }^{2}$, and the average column efficiency 97.4 percent.

The program and testing procedure were prepared by $\mathrm{O}$. H. Ammann, chief engineer; L. S. Moisseiff, consulting engineer; and R. S. Johnston, research engineer, of the Port of New York Authority; and by L. J. Briggs, L. B. Tuckerman, and H. L. Whittemore, of the National Bureau of Standards. The following members of the staff of the Port of New York Authority assisted in making the tests and obtaining the data: A. H. Baker, F. J. Hinners, S. K. Hoppen, B. A. Lefeve, L. D. Mork, R. B. Morris, and G. A. Woods.

The chemical compositions of the steels were determined by the Chemistry Division of the Bureau.

Washington, February 27, 1935. 